\title{
The Current Trend in the Fusion of Wayang Kulit Performance Styles from the 'Keraton' Tradition and 'Folk' Tradition
}

\author{
Sugeng Nugroho Sunardi I Nyoman Murtana \\ Faculty of Performing Arts, Institut Seni Indonesia Surakarta \\ Jln. Ki Hadjar Dewantara 19 Kentingan, Jebres, Surakarta
}

\begin{abstract}
The research is financed by Ministry of Research, Technology and Higher Education of the Republic of Indonesia through Competency Grants.

\section{Abstract}

The aim of this research is to analyze the performance styles of wayang kulit purwa (classical shadow puppet theatre) from the keraton (court) tradition and the folk tradition in the past and present day. The research subject about the performance of wayang kulit from the keraton tradition is limited to Surakarta style wayang kulit performance, and the research subject about the performance of wayang kulit from the folk tradition includes East Javanese style and Kedu style. The problem discussed in this study is the cultural interaction between dalang (puppeteers) from the keraton tradition and the folk tradition. The research uses a qualitative method with an analytical descriptive analysis. The research data was collected through a library study, documentary study, observation, and interviews. The results of the research show that the performance of wayang kulit purwa in the present day has become diluted in terms of its performance style. Artistic elements from the folk tradition have been absorbed into the performances of dalang from the keraton tradition, and vice versa. The orientation of the performance of wayang kulit purwa in the present day is no longer simply for the audience to enjoy its storyline but also to entertain. Nevertheless, a complete aesthetical nuance is only present in wayang kulit performances from the ex-keraton tradition, while performances of wayang kulit from the folk tradition remain oriented to the nuances of gayeng (lively) and gobyog (dynamic).
\end{abstract}

Keywords: wayang kulit performance, keraton tradition, folk tradition, fusion of styles.

DOI: $10.7176 /$ ADS/76-07

Publication date:September $30^{\text {th }} 2019$

\section{Introduction}

The tradition of wayang kulit performance in Java can essentially be divided into two traditions, the 'keraton' or 'court' tradition and the 'folk' tradition. The keraton tradition of wayang kulit performance is a performance style that existed and developed in the cultural elite communities (of the keraton or kadipaten). The aesthetics of this performance style are intricate (ngrawit) and complex within a complete, whole entity, and include the nuances of regu, greget, sem, and nges. Regu describes a nuance that is sacred, grand, commanding, solemn, calm, and steady, which is generated by the garap pakeliran (the way the performance style is treated). Greget is a nuance generated by the garap pakeliran that creates an impression of being excited, tense, hurried, awkward, rough, simple, angry, and frightening. Sem refers to a nuance generated by the garap pakeliran that is pleasant, lustful, mischievous, agile, restless, flirtatious, fluid, relaxed, and romantic. The nuance of nges generated by the garap pakeliran creates an impression that is compassionate, pitiful, remorseful, sad, confused, upset, cold, and lonely (Nugroho, 2012). The folk tradition of wayang kulit performance is a performance style that existed and developed in agrarian village communities. The aesthetical nuances of this performance style are fluid, straightforward, rough, humorous, cheerful, and animated (ramé), gayeng or gobyog (Kayam, 1981). The concept of gayeng and gobyog creates an impression of festivity, joy, fluidity, loudness, harshness, roughness, and agility, which all combine to form a single aesthetical entity in the performance.

The keraton tradition of wayang kulit performance was born out of the initiative of Susuhunan Paku Buwana X, king of the Kasunanan Keraton in Surakarta (1893-1939). The background to the emergence of this tradition was the concern of the aristocracy about the performance conditions of dalang at that time, since they were unable to follow the developments in society, and especially the intellectual community. Therefore, in 1923, Paku Buwana X established a school for dalang, which was given the name Pasinaon Dhalang ing Surakarta (abbreviated to PADHASUKA), and taught the art of puppetry in the style of the Kasunanan Keraton. Sultan Hamengku Buwana VIII, king of the Kasultanan Keraton in Yogyakarta (1912-1939) followed the example of Paku Buwana X, and in 1925 he established a school for dalang, which was given the name Hanganakaké Biwara Rancangan Padhalangan (abbreviated to HABIRANDHA), and taught the art of puppetry in the style of the Kasultanan Keraton. Subsequently, K.G.P.A.A. Mangkunegara VII, Adipati Mangkunegaran Surakarta (1916-1944), not wanting to be left behind, also founded a school for dalang in 1931, a school that was called Pasinaon Dhalang ing Mangkunegaran (abbreviated to PDMN) and taught the art of puppetry in the style of the Mangkunegaran. The students at these three schools were mostly dalang from the folk tradition who were already popular in their own areas. They studied the art of puppetry in the keraton not only to improve the 
quality of their own skills but also to learn how to make their performances more appealing to wayang audiences (Van Groenendael, 1987).

The different styles of wayang kulit performance in the folk tradition were shaped by the style of performance of particular dalang which was then passed on to his children, grandchildren, great-grandchildren, and so on. The process of transmitting style from one generation to another was carried out not through a formal learning system but through performance. The different folk styles of wayang kulit existed and developed in areas far from the former centers of the Javanese kingdoms, or in rural, mountain, and coastal regions. The styles of performances are quite diverse because each area has its own sources of reference (Van Groenendael, 1987). In East Java there are four sub-styles: (1) Lamongan (found in and around the Lamongan area), (2) Mojokertoan (found in and around the areas of Jombang and Mojokerto), (3) Porongan (found in and around the areas of Sidoarjo and Surabaya), and (4) Malangan (found in and around the Malang area). In Central Java there is Kedu style (with the sub-styles Magelangan, Temanggungan, Wonosaban, and Bagelènan) (Panitia Sarasehan, 1988) and Banyumasan style (with the sub-styles pesisiran [coastal] and lor gunung [north of the mountain]) (Senawangi, 1983).

This research aims to answer the following questions: (1) what is the general form of wayang kulit performance from the keraton tradition today? (2) what is the general form of wayang kulit performance from the folk tradition today? and (3) why is there a fusion of styles in the art of puppetry in wayang kulit performances today?

These three problems are studied based on the paradigm of sociology of art introduced by Arnold Hauser (1974), who explained that according to its cultural strata, art can be divided into four categories: elite art, folk art, popular art, and mass art. The first category, elite art, refers to high art or classical art that exists in the communities of the cultural elite, such as aristocrats, officials, and other elite rulers, and is characterized by intricate and complex aesthetical values. The second category, folk art, refers to art that exists in and is rooted in and enjoyed by rural agrarian communities. This art is simpler, spontaneous in nature and is not required to have a high aesthetical value. The third category, popular art, refers to art that exists in and is enjoyed by urban communities. This type of art is more inclined to prioritize the pragmatism of entertainment and acts as a means of relaxation and escape from the boredom experienced by working people, and it is therefore easy for the listener to digest without the need for any deep reflection and appreciation. The fourth category, mass art, refers to art that is produced by mechanical equipment and has a diverse audience. This type of art is industrial art that is marketed for the purpose of entertainment.

\section{Literature Review and Research Method}

This research about the fusion of performance styles, both in wayang kulit performances from the keraton tradition and wayang kulit performances from the folk tradition, is urgently needed because no previous scientific studies have been carried out on this subject. Most existing studies about wayang kulit performance are still partial in nature, focusing either on the keraton tradition or the folk tradition, but not discussing both traditions in a single study. Below are the results of studies that are related to this current study.

Bambang Murtiyoso's research entitled "Faktor-faktor Pendukung Popularitas Dalang" (1995) discusses the social and cultural aspects that influence the popularity of dalang who follow the performance style of the Surakarta keraton tradition, with specific reference to Anom Soeroto and Manteb Soedharsono. The study entitled "Pertunjukan Wayang Kulit di Jawa Tengah Suatu Alternatif Pembaharuan, Sebuah Studi Kasus," by Kuwato (2001), investigates the performance of wayang pantap in Central Java, as an alternative innovation in the performance of wayang kulit in the keraton traditions of Surakarta and Yogyakarta. Another research study, Kelir Tanpa Batas, by Umar Kayam (2001) discusses the changes in order that took place in the world of shadow puppet theater at the end of the $1990 \mathrm{~s}$. He states that at that time, the tradition of shadow puppet theater in Java was becoming more open to the idea of combining various different idioms of wayang performance from the different styles that existed. However, Kayam's study is limited only to the situation in which the traditional keraton style is starting to become less apparent in performances of Surakarta style wayang by popular dalang, but it does not mention the inclusion of keraton style in performances of wayang kulit in the folk tradition.

Most of the articles about wayang kulit performance from the folk tradition are informative and documentative in nature. The result of a documentation by Sekretariat Nasional Pewayangan Indonesia, entitled Pathokan Pedhalangan Gagrag Banyumas (1983), discusses the life of wayang and the foundations of a Banyumasan style wayang kulit performance. Soenarto Timoer's article Serat Wewaton Pedhalangan Jawi Wétanan (1988), analyzes the origins and existence of East Javanese wayang and the orientation of East Javanese wayang performance, with a description of an East Javanese wayang kulit performance and a bibliography of essays written by East Javanese literary scholars that are used as the guidelines for East Javanese wayang performance. "Ki Ageng Kedu dalam Pakeliran Ruwatan Tradisi Kedu," a study by Ig. Krisna Nuryanta Putra (1999), discusses the history of the development of Kedu style wayang kulit, the form and characteristics of the puppets, the performance equipment, performance structure, elements of garap pakeliran, and the lakon 
(stories) performed. Suyanto's study entitled Wayang Malangan (2002) discusses the origins and existence of the Malangan sub-style of wayang kulit performance.

This current study uses a qualitative method with an analytical descriptive analysis. The research data was collected through a library study, documentary study, observation, and interviews. The library study focused on books and manuscripts about wayang kulit performance in the keraton tradition and folk tradition. The documentary study concentrated mainly on a number of audio-visual recordings of wayang kulit performances in the keraton tradition and folk tradition. The field observation of numerous wayang kulit performances in the keraton tradition was carried out since the 1990s, while the field observation of wayang kulit performances in the folk tradition was carried out since 2017. Interviews were held with a number of dalang and wayang kulit experts.

\section{Research Results and Analysis}

\subsection{Performance of Wayang Kulit in the Keraton Tradition in the Past and Present Day}

The performance of wayang kulit in the (Surakarta) keraton tradition in the past (1923-1950s) can be differentiated according to three types: (1) wayang purwa, which presents the Ramayana and Mahabharata stories; (2) wayang madya, which presents stories about Javanese kings from the time of Prabu Gendrayana in Hastina up to the time of the kings of Medang Kamulan, Pengging, and Prambanan; and (3) wayang gedog, which presents the stories of Panji. These three types of wayang performance are distinguished by the shape and form of their wayang figures or puppets. Wayang kulit purwa has a very complete set of figures, ranging from gods to holy men, kings, gallant knights, refined knights, princesses, officials, apes, giants, knights' servants, giants' servants, maids, animals, troops of soldiers, and vehicles. Several different shapes are used for the lower part of the male wayang figures, including: (1) figures dressed in long trousers, covered in a hanging-down cloth, and decorated with accessories called uncal kencana and uncal wastra, known as wayang jangkahan kuncan; (2) figures dressed in short trousers reaching down to the knee and covered in a hanging-down cloth, known as wayang jangkahan dhengkulan; (3) figures wearing a wrap-around cloth with a rounded backside, known as wayang bokongan; and (4) figures wearing short or long trousers, with a cloth that tapers down to cover the back leg, and a keris (dagger), known as wayang rapèkan. Wayang (kulit) madya do not have such a complete set of figures as wayang kulit purwa, including only three gods (Guru, Narada, and Yamadipati), and only the single ape figure of Anoman. All the male figures wear cloth in the form of rapèkan and carry a keris. Wayang (kulit) gedog is not only less complete than wayang kulit purwa but also includes no apes or giants. All the male figures wear a skull cap known as a tekes, with a wrap-around cloth shaped like a goose's tail, called a rapèk banyakan, and carry a keris. None of the kings wear a crown (kuluk or makutha) but instead their hair is either coiled into a bun, known as a gelung keling, or covered with a headband decorated like the head of the mythical garuda bird facing backwards, known as a jamang pogokan, and a tress of jasmine flowers, called oncèn-oncèn decorating the ear.

Since the 1990s, wayang kulit purwa figures have begun to display a fusion of forms. Some of the male wayang figures have been modified in the shape of wayang madya and wayang gedog figures. Some of the figures of kings and gallant knights, which were originally in the shape of jangkahan kuncan, have been altered into the shape of the rapèkan figures used in wayang madya. These include the figures of Ramawijaya and Lesmanawidagda, the figure of Baladewa after the battle of Baratayuda, the figure of Setyaki which is used for the figure of Sanga-sanga, the figure of Antareja which is used for the figure of Danurwenda, the figure of Gathutkaca which is used for the figure of Sasikirana, and the figures of raja seberang. Some of the raja seberang wear jamang pogokan and oncèn-oncèn like the figure of Klana in wayang gedog.

The performance of wayang kulit in the (Surakarta) keraton tradition from 1923 to the 1950s can be differentiated according to the use of gamelan instruments that accompany the performance. Performances of wayang kulit purwa are accompanied by a gamelan ensemble in sléndro tuning while wayang (kulit) madya performances are accompanied by a pélog gamelan ensemble, in which gending (musical compositions) in sléndro are transposed into pélog. Performances of wayang (kulit) gedog are accompanied by a pélog gamelan ensemble, with pélog gending. Since the 1960s, the performance of wayang kulit purwa has included pélog gamelan instruments as well as a sléndro ensemble. The gending used in a wayang kulit purwa performance are not limited to gending with a sléndro nuance that are transposed into pélog such as in wayang madya, but also include pélog gending such as in the performance of wayang gedog. In wayang kulit purwa performances by the dalang Nartasabda, the gending were not limited to gending garap wayangan (gending for wayang accompaniment), but also included gending garap klenèngan (gending for concert music) and garap bedhayan (gending for accompanying the bedhaya-srimpi dances). Similarly, in the performance of sulukan, the 'mood songs' sung by the dalang to set the scene, Nartasabda not only used the sulukan of wayang purwa but also the sulukan of wayang madya and wayang gedog. Since the 1990s, performances of wayang kulit purwa are no longer only accompanied by gamelan but also now include other instruments from outside the gamelan, such as drums, cymbals, organs, and guitars. The use of drums and cymbals is to create a stronger sound effect to 
accompany battle scenes, while the use of organs and guitars is to accompany campursari songs during the intermezzo scenes (limbukan and gara-gara).

The scene structure of wayang kulit purwa performances in the (Surakarta) keraton tradition from 1923 to the 1950s is made up of three acts, or pathet. The first act, pathet nem, consists of the opening court scene (jejer kerajaan), the gapuran scene, the kedhatonan scene, the paséban jawi scene, the sabrang kingdom scene, perang gagal, and the sabrang rangkep scene. The second act, pathet sanga, consists of the sanga sepisan scene, perang kembang, the sintrèn scene, and perang sintrèn or perang sampak tanggung. The third act, pathet manyura, consists of the manyura sepisan scene, the manyura pindho scene, perang manyura, the manyura ping telu scene, perang brubuh, the panutup scene, and ends with tanceb kayon (Nojowirongko, 1960; Wignjosoetarno, 1972). Since the 1970s, not all dalang include the gapuran scene. Since the 1990s, not all dalang include the gapuran scene, kedhatonan scene, sabrang rangkep scene, sintrèn scene, and perang sintrèn or perang sampak tanggung. On the contrary, they more often include the limbukan and gara-gara scenes, which were never included during the previous era. These two scenes are used as an intermezzo and also to convey social messages and present campursari songs, chosen either by the dalang himself or at the request of the audience.

A cross-over in the performance style of the keraton traditions, between the Surakarta and Yogyakarta styles began to take place in the 1960s, pioneered by Nartasabda. This included the choice of story, scene structure, gending repertoire, and sulukan repertoire. The repertoire of stories for Yogyakarta style wayang performance, featuring the figures of Sadewa, Antasena, and Wisanggeni as the protagonist and tritagonist characters, began to be adopted more frequently as the story repertoire for Surakarta style wayang performance. The gara-gara scene, which was always included at the beginning of the second act (pathet sanga) in Yogyakarta style performance, began to be used more frequently in Surakarta style performance. Prior to the era of Nartasabda, the gara-gara scene was only used for certain stories in Surakarta style wayang performance, such as for the lakon Palasara Krama and Arjuna Wiwaha. Srepeg Mataraman, which belongs to the gending repertoire for Yogyakarta style wayang, began to appear more frequently to accompany the end of the sabrang rangkep scene at the end of the first act (pathet nem) in Surakarta style wayang performance. Ada-ada Mataraman and Pathet Sanga Wetah, which are sulukan used in Yogyakarta style, started to be used as a signal for Srepeg Mataraman to be played at the end of the first act (pathet nem) and to start the second act (pathet sanga) in Surakarta style wayang performance.

The cross-over in performance styles of wayang kulit from the keraton tradition and the folk tradition began to appear in the 1980s, since the appearance of pakeliran padat (a condensed form of wayang kulit performance), pioneered by the Puppetry Department of Akademi Seni Karawitan Indonesia (ASKI) Surakarta on the initiative of S.D. Humardani. In the concept of pakeliran padat, it is said that the differences in puppetry traditions should not be treated as two conflicting entities, but rather they should be combined in an exploration of garap pakeliran to discover alternative 'aesthetics' for different scenes, in accordance with the wishes of the dalang. The several elements of garap pakeliran from the folk tradition that are often used in performances of Surakarta style wayang kulit purwa include the repertoire of gending and sulukan, from the folk tradition in Central Java (including the Klatènan, Wonogirèn, Sragènan, Kedu, and Banyumasan sub-styles) and also East Java (including the Tambakbayan, Madiunan, Ponoragan, Lamongan, Mojokertoan, Porongan, and Malangan sub-styles).

The differences between wayang kulit performances from the keraton tradition in the past and present day can be illustrated in the form of a table, as shown below: 
Table 1. The conditions of wayang kulit performance in the keraton tradition

\begin{tabular}{|c|c|c|}
\hline & Past (1923 to 1950s) & Present (1960s to 2018) \\
\hline $\begin{array}{l}\text { Performance } \\
\text { Equipment }\end{array}$ & $\begin{array}{l}\text { There was a clear distinction between the } \\
\text { puppets used in wayang kulit purwa, wayang } \\
\text { (kulit) madya, and wayang (kulit) gedog. }\end{array}$ & $\begin{array}{l}\text { Surakarta style wayang kulit purwa } \\
\text { began to adopt the forms of } \\
\text { wayang figures from wayang } \\
\text { (kulit) madya and wayang (kulit) } \\
\text { gedog. }\end{array}$ \\
\hline \multirow{3}{*}{$\begin{array}{l}\text { Performance } \\
\text { Structure }\end{array}$} & \multirow{2}{*}{$\begin{array}{l}\text { Scene structure was divided into three acts. } \\
\text { 1. Pathet nem: court jejer, gapuran scene, } \\
\text { kedhatonan scene, paséban jawi scene, } \\
\text { kerajaan sabrang scene, perang gagal, } \\
\text { ending with sabrang rangkep scene. } \\
\text { 2. Pathet sanga: sanga sepisan scene, perang } \\
\text { kembang, sintrèn scene, ending with perang } \\
\text { sampak tanggung. } \\
\text { 3. Pathet manyura: manyura sepisan scene, } \\
\text { manyura pindho scene, perang manyura, } \\
\text { manyura ping telu scene, perang brubuh, } \\
\text { panutup, ending with tanceb kayon. }\end{array}$} & $\begin{array}{l}\text { Since the } 1970 \text { s, there has been no } \\
\text { gapuran scene, but before the } \\
\text { sanga sepisan scene, there is } \\
\text { sometimes a gara-gara. }\end{array}$ \\
\hline & & $\begin{array}{l}\text { Since the } 1990 \mathrm{~s} \text {, there has been no } \\
\text { gapuran scene, kedhatonan scene, } \\
\text { sabrang rangkep scene, sintrèn } \\
\text { scene, or perang sampak } \\
\text { tanggung, but there is often a } \\
\text { limbukan scene (replacing the } \\
\text { kedhatonan scene) and gara-gara } \\
\text { (at the beginning of the pathet } \\
\text { sanga section). }\end{array}$ \\
\hline & $\begin{array}{l}\text { Surakarta style wayang performance presented } \\
\text { Surakarta versions of the story repertoire, while } \\
\text { Yogyakarta style wayang performance } \\
\text { presented Yogyakarta versions of the story } \\
\text { repertoire. }\end{array}$ & $\begin{array}{l}\text { Surakarta style wayang } \\
\text { performance frequently adopts } \\
\text { Yogyakarta versions of the story } \\
\text { repertoire. }\end{array}$ \\
\hline \multirow{2}{*}{$\begin{array}{l}\text { Performance } \\
\text { Texture }\end{array}$} & \multirow{2}{*}{$\begin{array}{l}\text { Surakarta style wayang performance presented } \\
\text { gending and sulukan purely in Surakarta style, } \\
\text { while Yogyakarta style wayang performance } \\
\text { presented gending and sulukan purely in } \\
\text { Yogyakarta style. }\end{array}$} & $\begin{array}{l}\text { Since the } 1960 \text { s, Surakarta style } \\
\text { wayang performance has } \\
\text { frequently adopted Yogyakarta } \\
\text { style gending and sulukan. }\end{array}$ \\
\hline & & $\begin{array}{l}\text { Since the 1980s, Surakarta style } \\
\text { wayang performance has } \\
\text { frequently adopted gending and } \\
\text { sulukan from the folk styles of } \\
\text { Central Java and East Java. }\end{array}$ \\
\hline
\end{tabular}

3.2 Performance of Wayang Kulit in the Folk Tradition in the Past and Present Day

Based on its cultural locus, wayang kulit in the folk tradition can be differentiated into three main styles: East Javanese style (including Lamongan, Mojokertoan, Porongan, and Malangan), Kedu style (including: Magelangan, Temanggungan, Wonosaban, and Bagelènan), and Banyumas style (including pesisiran and lor gunung). Each of these styles of wayang performance has its own characteristics. The shapes of the puppet figures in East Javanese style wayang kulit purwa are similar to those in Cirebon style wayang kulit purwa, but from the waist down, the figures tend to be more slender, like the puppets in Surakarta style wayang kulit purwa. The figures of gallant knights (Werkudara, Antareja, and Gathutkaca) have red faces and the tips of their hair buns are not stuck to the crown of their heads as in Cirebon style wayang kulit. The wayang kulit purwa figures in Kedu style and Banyumas style have fatter bodies, like the figures in Yogyakarta style wayang kulit purwa, but from the waist down they tend to be more slender, like the puppets in Surakarta style wayang kulit purwa. The figures of gallant knights such as Werkudara, Antareja, and Gathutkaca have black faces and red moustaches, like those in Yogyakarta style wayang kulit purwa. The gradation of the colour (sorotan sunggingan) on the clothes of East Javanese puppets tends to have a green nuance, while the clothes of the puppets in Kedu and Banyumas style tend to have a red nuance.

East Javanese style wayang kulit performances always begin with a traditional East Javanese dance, Ngréma, performed in two styles - female and male. This dance is performed from $8 \mathrm{pm}$ until $10 \mathrm{pm}$, to 
welcome the arrival of the guests, and at the same time as an invitation for the audience to come and watch the wayang kulit performance. As well as dancing, the Ngréma dancers sing songs requested by guests or members of the audience. In addition, the guests or audience members often dance or sing along with the Ngréma dancers, creating an atmosphere that is ramé gayeng, even before the performance of wayang kulit purwa begins.

The scene structure is made up of three acts. The first act, accompanied by gending with a nuance of pathet sepuluh and pathet wolu, consists of: jejer kerajaan, jejer paséban, perang sepisan, and jejer kerajaan. The second act, accompanied by gending in pathet sanga, consists of jejer pertapaan or a scene in a hermitage or the middle of a forest, perang gagal or perang bégal, and jejer kerajaan. The third act, accompanied by gending with a nuance of pathet serang, consists of: jejer kerajaan seberang, perang brubuh, jejer pamungkas, a court scene, and tanceb kayon. Traditionally, East Javanese wayang kulit performance does not include a kedhatonan scene, limbukan, or gara-gara. The jokes presented by the panakawan figures (Semar, Bagong, and Besut) are included in the jejer pertapaan or the scene in the hermitage or middle of the forest. However, since the 1990s, the performance of East Javanese wayang kulit has begun to include limbukan and gara-gara scenes like in Surakarta style wayang kulit performance.

The structure of the narration of the janturan jejer in East Javanese style has similarities with the narration of the janturan jejer in Surakarta style wayang kulit performance, and consists of: the introduction, the name of the kingdom, a description of the geographical situation, the economic situation, the situation of peace and wellbeing in the kingdom, and the loyalty of the court officials, the king's name, its meaning, and a description of his character. Similarly, the structure of the dialogue of the first jejer is similar to the structure of the dialogue in Surakarta style wayang kulit performance, namely a clichéd dialogue followed by dialogue about the general topic of the scene. The similarities between the dialogue of wayang characters in East Javanese style and Surakarta style wayang kulit performance are also apparent in the dialect and idiolect of the wayang characters.

Kedu style wayang kulit performances are divided into three acts: pathet nem, pathet sanga, and pathet manyura. Pathet nem begins with jejer I set in a kingdom, continuing with kedhatonan, paseban jawi, and budhalan. Jejer II is set in a hermitage or in another kingdom - sabrang gagah or alus, and continues with perang simpangan. Pathet sanga begins with jejer III, which portrays the journey of a group of soldiers, and continues with perang gagal, the gara-gara scene, and jejer IV in which the panakawan appear before the knights or holy men, ending with perang bégal between the knights and the giants. Pathet manyura begins with jejer $\mathrm{V}$, continuing with budhalan and perang panggah, jejer VI continues with perang ageng or perang brubuh, followed by jejer VII, a dance of wayang golek, and ending with tanceb kayon. Originally, Kedu style performance did not have a limbukan or gara-gara scene, but since the 1990s, limbukan and gara-gara scenes have been included in the performance, as in the case of Surakarta style wayang kulit performance.

A performance of wayang kulit in Kedu style does not include battles between the different characters. The reason for this is to look after the wayang puppets to preserve their condition so that they last longer. Instead, there is a battle known as perang pengabaran, which is a non-physical battle to contest the supernatural powers of two figures. For example, one figure throws his belt buckle (timang) to the ground and it changes into a tiger, then his adversary throws down his belt and it turns into a buffalo. These two animal figures then compete in a battle.

The differences between wayang kulit performances from the folk tradition in the past and present day can be illustrated in the form of a table, as shown below: 
Table 2. Conditions of wayang kulit performance in the folk tradition

\begin{tabular}{|c|c|c|}
\hline & Past & Present \\
\hline \multirow{2}{*}{$\begin{array}{l}\text { Performance } \\
\text { Equipment }\end{array}$} & $\begin{array}{l}\text { East Javanese style wayang kulit figures were similar to Cirebon } \\
\text { style, but from the waist down they tended to be more slender, } \\
\text { like Surakarta style wayang kulit purwa figures. Gradations in the } \\
\text { colour (sorotan sunggingan) of the clothes tended to have a } \\
\text { nuance of green. }\end{array}$ & No changes. \\
\hline & $\begin{array}{l}\text { Kedu and Banyumasan wayang kulit figures were fat, like the } \\
\text { wayang kulit purwa puppets in Yogyakarta style, but from the } \\
\text { waist down they tended to be more slender, like Surakarta style } \\
\text { wayang kulit purwa figures. Gradations in the colour (sorotan } \\
\text { sunggingan) of the clothes tended to have a nuance of red. }\end{array}$ & No changes. \\
\hline \multirow[t]{2}{*}{$\begin{array}{l}\text { Performance } \\
\text { Structure }\end{array}$} & $\begin{array}{l}\text { 1. East Javanese style wayang kulit performances always began } \\
\text { with the male and female styles of the Ngréma dance. } \\
\text { 2. Scene structure was divided into three acts. } \\
\text { a. The first act (pathet sepuluh and pathet wolu) consisted of: } \\
\text { jejer kerajaan, jejer paséban, perang sepisan, ending with } \\
\text { jejer kerajaan. } \\
\text { b. The second act (pathet sanga) consisted of: jejer } \\
\text { pertapaan or a scene in a hermitage or the middle of a } \\
\text { forest, perang gagal or perang bégal, ending with jejer } \\
\text { kerajaan. } \\
\text { c. The third act (pathet serang) consisted of: jejer kerajaan } \\
\text { seberang, perang brubuh, jejer pamungkas, court scene, } \\
\text { ending with tanceb kayon. } \\
\text { 3. There were no kedhatonan, limbukan, or gara-gara scenes. }\end{array}$ & $\begin{array}{l}\text { 1. East Javanese style } \\
\text { wayang kulit } \\
\text { performance always } \\
\text { begins with either the } \\
\text { male or female style } \\
\text { of the Ngréma dance. } \\
\text { 2. There have been } \\
\text { changes made to the } \\
\text { scene structure, with } \\
\text { the inclusion of } \\
\text { limbukan and gara- } \\
\text { gara scenes. }\end{array}$ \\
\hline & $\begin{array}{l}\text { 1. Kedu style wayang kulit performances were divided into three } \\
\text { acts. } \\
\text { a. Pathet nem: jejer I set in a kingdom, kedhatonan, paseban } \\
\text { jawi, budhalan, jejer II set in a hermitage or another } \\
\text { kingdom - sabrang gagah or alus, ending with perang } \\
\text { simpangan. } \\
\text { b. Pathet sanga: jejer III, perang gagal, gara-gara scene, } \\
\text { jejer IV, ending with perang bégal. } \\
\text { c. Pathet manyura: jejer V, budhalan, perang panggah, jejer } \\
\text { VI, perang ageng or perang brubuh, jejer VII, wayang } \\
\text { golek dance, ending with tanceb kayon. } \\
\text { 2. There were no limbukan or gara-gara scenes. }\end{array}$ & $\begin{array}{l}\text { There have been changes } \\
\text { made to the scene } \\
\text { structure, with the } \\
\text { inclusion of limbukan and } \\
\text { gara-gara scenes. }\end{array}$ \\
\hline \multirow{2}{*}{$\begin{array}{l}\text { Performance } \\
\text { Texture }\end{array}$} & $\begin{array}{l}\text { The structure of the narration of the janturan and the dialogue in } \\
\text { the first jejer in East Javanese style had similarities with the } \\
\text { narration of the janturan and dialogue in the jejer in Surakarta } \\
\text { style wayang kulit performance. }\end{array}$ & No changes. \\
\hline & $\begin{array}{l}\text { In Kedu style wayang kulit performances, there were no battles } \\
\text { between the different characters; instead perang pengabaran was } \\
\text { used. }\end{array}$ & No changes. \\
\hline
\end{tabular}

\subsection{Background to the Fusion of Styles of Wayang Kulit Performance}

At the time when the Kasunanan Keraton in Surakarta, Kasultanan Keraton in Yogyakarta, and Kadipaten Mangkunegaran in Surakarta still held political power (prior to the proclamation of independence of the Republic of Indonesia in 1945), folk artists always followed the models of the cultural products of these royal courts, and this was also the case with the performance of wayang kulit. The purity of the performance styles of wayang in each keraton was maintained by the dalang who adhered to these styles. In fact, even the folk dalang who had never studied in any of the keraton schools for dalang tried their best to present their performances of wayang kulit in the particular style of the keraton in the hope of increasing its appeal for wayang audiences.

As the times changed (after the proclamation of Indonesian independence in 1945), and the keraton, as cultural centers, no longer had their own experts in the art of wayang kulit, the main point of reference in the world of shadow puppet theater shifted orientation to those dalang who had gained a higher level of popularity than their counterparts at the time, such as Nartasabda and Anom Soeroto (for Surakarta style dalang) and Timbul Hadiprayitna and Hadisugita (for Yogyakarta style dalang). The emergence of Nartasabda's own unique 
style of wayang kulit performance in the early 1960s opened up the way for the fusion of different styles in the performance of wayang kulit. Nartasabda had the courage to lighten the atmosphere of the very first scene (jejer) of a performance, set in a kingdom, from what was traditionally a very serious, majestic, commanding scene to become a more relaxed, humorous, and playful scene. Likewise, since the innovations in the style of wayang kulit performance, pioneered by the Puppetry Department at ASKI Surakarta (in the early 1980s), known as the concept of pakeliran padat, the previously clearly-defined boundaries between Surakarta style and Yogyakarta style wayang kulit performance began to fade, as did the boundaries between the keraton tradition and folk tradition of wayang kulit performance. The exquisite orientation of the world of shadow puppet theater is not due to its inherently court-centric nature but rather because of the contextuality of a wayang kulit performance, and the extent to which a dalang can present an aesthetical nuance to suit the performance of a particular scene. This means that in order to be attractive, a wayang performance should not only contain nuances of regu, greget, sem, and nges, but must also be gayeng and gobyog (see the earlier explanation of these terms).

The orientation of wayang kulit purwa performance since the 1990s has not always been as a work of art to be appreciated and enjoyed for its storyline, but also as a work of art that must have the ability to entertain the audience. For this reason, aspects of kitsch art such as tricks, gimmicks, glamour, sex appeal, and sensationalism, have also become additional requirements in the performance of wayang kulit. Nevertheless, the complete aesthetical nuance that includes regu, greget, sem, nges, gayeng, and gobyog is only found in performances of wayang kulit in the style of the ex-keraton traditions (Surakarta and Yogyakarta), while performances of wayang kulit in the style of the folk tradition remain oriented towards nuances of gayeng and gobyog, and have not yet touched upon the nuances of regu, greget, sem, and nges.

The background to the fusion of styles in wayang kulit performance can be observed in terms of its external and internal factors. In terms of its external factors, the phenomenon of the fusion of wayang kulit performance styles has been influenced by: (1) changes in global culture, such as the process of cultural assimilation or changes in value systems upheld in a community; (2) the influence of printed and electronic media, which have had implications on the awareness of openness in society and in the art of wayang performance; and (3) the pressure of dominant authorities, which culturally have the power to shape the face of wayang performance. In terms of the internal factors, the fusion of performance styles of wayang kulit has been influenced more by: (1) the decline in locality and local identity of dalang and their public as a result of traditions becoming more open; (2) dalang attempting to legitimize themselves by demonstrating their extraordinary powers to perform various styles of wayang kulit within their own major style; and (3) reasons of creativity and innovation, as a result of which dalang have made new breakthroughs by adopting various elements of garap pakeliran from various styles of wayang kulit in their own performances (Sunardi, 2012:214-220).

\section{Conclusion}

The performance of wayang kulit purwa as a work of traditional art has undergone continual change in accordance with the development of its community. Its noble values, which in the past were oriented towards the keraton tradition, have now faded, and as a result the nuance of gayeng and gobyog that characterizes the aesthetics of the folk style of wayang kulit now also colours the performance of wayang kulit purwa. Even certain aspects of kitsch art that were formerly only found in popular art and mass art have now begun to colour the performance of wayang kulit, both in the keraton tradition and the folk tradition. The reason for this is simply to capture the attention of audiences so that they continue to enjoy watching wayang kulit performances. Therefore, at the present time there are no longer any clear boundaries between the performance of wayang kulit in the keraton tradition and wayang kulit in the folk tradition. The performance of wayang kulit is no longer only an inspiring and vivifying art but has also become a popular and entertaining art.

\section{References}

Kayam, Umar. (1981). Seni, Tradisi, Masyarakat. Jakarta: Penerbit Sinar Harapan.

(2001). Kelir Tanpa Batas. Yogyakarta: Gama Media.

Kuwato. (2001). "Pertunjukan Wayang Kulit di Jawa Tengah Suatu Alternatif Pembaharuan: Sebuah Studi Kasus.” Tesis S-2 Program Pascasarjana Universitas Gadjah Mada Yogyakarta.

Murtiyoso, Bambang. (1995). "Faktor-faktor Pendukung Popularitas Dalang." Tesis S-2 Program Pascasarjana Universitas Gadjah Mada Yogyakarta.

Nojowirongko, M.Ng. al. Atmotjendono. (1960). Serat Tuntunan Pedalangan Tjaking Pakeliran Lampahan Irawan Rabi. Jogjakarta: Tjabang Bagian Bahasa, Djawatan Kebudajaan Departemen P.P. dan K.

Nugroho, Sugeng. (2012). Lakon Banjaran: Tabir dan Liku-likunya, Wayang Kulit Purwa Gaya Surakarta. Surakarta: ISI Press.

Nuryanta Putra, Ig. Krisna. (1999). "Ki Ageng Kedu dalam Pakeliran Ruwatan Tradisi Kedu.” Tesis S-2 Program Pascasarjana Universitas Gadjah Mada Yogyakarta.

Panitia Sarasehan Pedalangan Kabupaten Temanggung. (1988). Sekilas Pengertian dan Tata Cara Pokok-pokok 
Pedalangan Gaya Kedu. Temanggung: Seksi Kebudayaan Kantor Departemen Pendidikan dan Kebudayaan. Senawangi. (1983). Pathokan Pedhalangan Gagrag Banyumas. Jakarta: Sekretariat Nasional Pewayangan Indonesia.

Sunardi. (2012). "Silang Gaya Pedalangan dalam Perspektif Perubahan Budaya," dalam Gelar Jurnal Seni Budaya, Vol. 10 No. 2 (Desember).

Suyanto. (2002). Wayang Malangan. Surakarta: Citra Etnika.

Timoer, Soenarto. (1988). Serat Wewaton Pedhalangan Jawi Wetan, Jilid I dan II. Jakarta: Balai Pustaka. Van Groenendael, Victoria Maria Clara. (1987). Dalang Di Balik Wayang. Jakarta: Pustaka Utama Grafiti.

Wignjosoetarno, Ng. (1972). Lampahan Makutarama: Pedalangan Ringgit Purwa Watjutjal. Surakarta: Jajasan PDMN. 